\title{
Effects of different land-use systems (grazing and understory cultivation) on growth and yield of semi-arid oak coppices
}

\author{
Ali Soltani ${ }^{1} \cdot$ Hamdollah Sadeghi Kaji ${ }^{1} \cdot$ Saleh Kahyani $^{1}$
}

Received: 25 April 2019 / Accepted: 20 August 2019 / Published online: 30 October 2019

(C) The Author(s) 2019

\begin{abstract}
The present study examines the extent of negative effects of traditional multiple land-use systems on oak coppices, from a forest management point of view. The study area was located in approximately 10,000 ha of hilly Brant's oak (Quercus brantii Lindl.) woodlands in the central Zagros Mountains. In the same site-quality class, three land-use systems were compared: simple coppice (Co), coppice in conjunction with small ruminant grazing $(\mathrm{CoG})$, and coppice with understory rain-fed wheat cultivation plus grazing (CoCG). Data on total wood volume of trunk and major branches, and annual ring growth, were collected and analyzed from 74 stands in 15 coppiced woodland patches. The results showed the advantage of $\mathrm{Co}$ over $\mathrm{CoG}$ and $\mathrm{CoCG}$ land-uses by 43 and $60 \mathrm{~m}^{3}$ of mean accumulated wood volume per hectare, respectively. The diameter growth analysis also revealed an annual increase in wood production of trees in Co land-uses over 43 years, with an exception of the recent decade, when growth coincided with a severe drought. Using a back-extrapolation method, the minimum rotation age of woodlands in Co land-use was found to be 23.6 years, 5 and 7 years shorter than those of $\mathrm{CoG}$ and CoCG land-uses, respectively. Unlike CoCG, woodlands located in $\mathrm{Co}$ and $\mathrm{CoG}$ land-use systems demonstrated a
\end{abstract}

Project funding: The work was supported by Ph.D. project of Shahrekord University.

The online version is available at http://www.springerlink.com

Corresponding editor: Tao Xu.

Ali Soltani

ali.soltani@sku.ac.ir

1 Department of Forest Science, Faculty of Natural Resources and Earth Sciences, Shahrekord University, P.O. Box 115, Shahrekord, Iran high level of agreement with self-thinning rule of $-3 / 2$. Values for the stand density index for coppiced oak woodlands were between more than 1000 for the least disturbed (Co) and less than 400 for the most disturbed woodlands (CoCG). The structure and growth rate of the coppiced oak woodlands were irreversibly disrupted by understory tillage plus grazing and in less extent by grazing alone. It was concluded that ending undergrowth cultivation in semi-arid oak coppices should be addressed as a priority by adopting minimum regulations.

Keywords Coppicing - Land-use impact assessment . Diameter growth $\cdot$ Multi-purpose land-use $\cdot$ Self-thinning rule $\cdot$ Stand density index

\section{Introduction}

The continued degradation of semi-arid oak forests due to multiple and excessive use of land resources is a global problem (Kosmas et al. 2002; Plieninger et al. 2011). On the one hand, the traditional and mostly illegal extractions of wood and charcoal have transformed these forests into coppiced woodlands (Salehi et al. 2008; Bishop et al. 2018; Kabukcu 2018) as a result of the potent shooting capability of oaks. On the other hand, overgrazing and understory cultivation often lead to soil erosion and seedling recruitment failure (Dupouey et al. 2002). The gradual decline of these woodlands is often described by setbacks in their boundary or decreases in their tree density (Pardo and Gil 2005; Soltani et al. 2015). Certain sustainability indices of biodiversity and soil properties have also been considered in this regard (Kleine et al. 2009; Khaledian et al. 2012). However, possible decreases in growth and yield of the coppiced oak woodlands under multiple land-use systems have received 
less attention. This lack of attention may be related to two issues. First, there is a general tendency to consider coppices as less susceptible to "further" excessive multiple land-uses when they are compared to high-forests (Sadeghi Kaji and Soltani 2017). This assumption comes from the fact that the main competition for growing space in coppices occurs among shoots (raments) grown on each stool (genet), rather than between individual trees (rootstocks) (Johnson et al. 2009). Second, priorities have often been given to protection and not to rational planning of changes to the management of existing threatened coppices (Buckley 1992; Müllerová et al. 2015).

Nevertheless, another alternative to the protection of the oak coppices is to have a moderate degree of hemeroby in order to convert them into other silvicultural systems like coppice with standards or high-forests (Mohajer 2013; Nyland 2016). In that condition and to initiate the primary cutting programs, foresters have to know that to what extent the multiple land-uses affect the yield and growth of coppiced oak woodlands.

From the forestry standpoint, several criteria and techniques are available to measure the sustainability of forest yield and to evaluate the effects of man-made disturbances on a woodland (Fujimori 2001; Reid 2009). Maintenance of the productive capacity of forest trees is among the most widely used criteria, that can simply be represented by the accumulated wood crop and by the annual wood growth rate over a period of time (Xu et al. 1995). Change in trajectory of extrapolated volume vs age curves is an old-school approach (Soares et al. 1995), which can be expressed as the concept of minimum rotation age (Burkhart and Tomé 2012). Another technique is to determine to what extent the relationship between the number of stems and the quadratic mean diameter of a pure fully stocked stand is diverted from the $-3 / 2$ power rule (Yoda et al. 1963). If these relationships as they are formulated, are not valid, it can be speculated that the disturbances caused by multi-purpose land-uses might cause reversible/irreversible deleterious effects on wood yield, and thereby, in long term, on survival of the coppices.

The answer to the question of whether multiple landuses have any significant effect on the sustainability of the whole system (the forest) is not straightforward. To date, no research has been conducted on the assessment of loss of productivity of coppiced trees due to the possible stresses resulting from multiple land-uses.

Previous studies have examined two views on the subject. Either they had a positive opinion and pointed to the increase in carbon sequestration and the productivity of the system as a whole (Kumar and Nair 2011; Gordon et al. 2018), or they echoed the undesirable socio-economic and ecological aspects of overgrazing and understory cultivation in woodlands (Le Houerou 2000). Vincent and Binkley (1993) have theorized the latter view and questioned the economic benefit of multiple use of land in forestry in a sense of lowering forest commodity.

For foresters who wish, in addition to protection, to convert the natural oak coppicing systems, this study was intended to assess the impact of the two most common forms of traditional land-use systems (grazing and understory cultivation plus grazing) on wood yield and growth of coppiced oak trees.

Comparing stand yield and growth under these conditions has its drawbacks, since each land-use system can have different effects according to different indices used. In addition, trees in most semi-arid oak coppices in multi-land systems have a higher average age than trees in simple coppices. To overcome these problems and achieve the desired goal, the present study aimed to statistically compare the key attributes of coppiced oak stands under different land-uses: (1) wood volume production, after age and site productivity corrections; (2) mean annual ring growth of the trees after sample standardization; (3) minimum rotation age required for production of poles for rural household needs; and (4) general self-thinning relationship of stands base on the $-3 / 2$ power rule and its related stand density index (SDI).

\section{Materials and methods}

\section{Study area}

The study area is located between $31^{\circ} 54^{\prime} 45^{\prime \prime}$ and $31^{\circ} 57^{\prime} 21^{\prime \prime}$ $\mathrm{N}$ latitude, $50^{\circ} 30^{\prime} 46^{\prime \prime}$ and $50^{\circ} 33^{\prime} 50^{\prime \prime} \mathrm{E}$ longitude, in the central Zagros Mountains with an average altitude of 1871 meters a.s.l. Seventy-four stand patches of pure, even-aged Brant's oak (Quercus brantii Lindl.) coppices were randomly selected in 15 main woodland districts (Fig. 1). None of the patches were less than 3 ha. They were visually homogeneous in terms of land-use and the uniformity of the tree distribution. The Provincial Natural Resources Bureau has documented their past or present history well. According to the Köppen climate classification, the region has a cold semi-arid climate.

These stand patches have been under different land-uses over the last five decades. Three forms of completely separate land-uses have been observed: (1) simple coppice, with no grazing or cultivation activity (hereafter referred to as Co); (2) coppiced woodlands used intensively as range land for moving livestock, mainly sheep and goats $(\mathrm{CoG})$, and (3) coppiced woodlands with both understory rain-fed wheat cultivation (for part of the year) and grazing (CoGC).

\section{Data collection}

Quadratic mean diameter at ground level $\left(D_{\mathrm{q}}\right)$, i.e., the diameter of average basal area, (with $5 \mathrm{~mm}$ accuracy) and 
Fig. 1 Location of the study site within the Zagros Mountains deduced from GPS measurements, designating 15 districts of main Brant's oak woodlands. The 74 patches within the districts are not indicated due to scale constraints

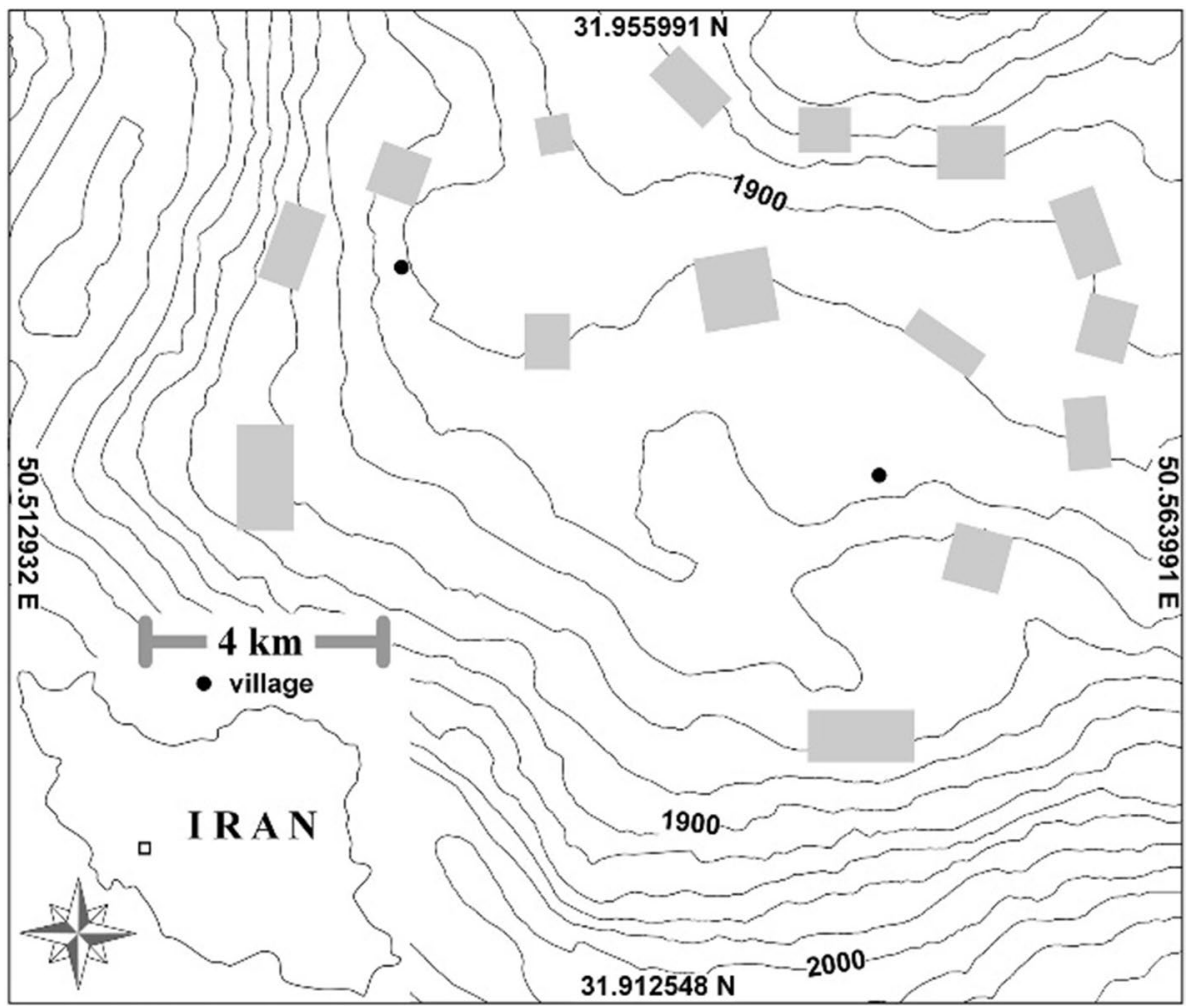

height (with $5 \mathrm{~cm}$ accuracy) of shoots thicker than $10 \mathrm{~cm}$ in diameter (a common local minimum diameter for charcoal production) were collected in 0.1 ha plots, which were randomly distributed on a $50 \times 50 \mathrm{~m}$ grid cells across each stand patch. In each plot, the height of the tallest tree was recorded as the dominant height $\left(h_{\mathrm{d}}\right)$. The volume of trunk and main branches $\left(V_{\mathrm{t}}\right)$ for every shoot in each plot was estimated by a combination of Hohenadl's form quotient for small trees (Laar and Akça 2007) and locally developed allometric equations (Askari 2017; Iranmanesh 2013). In addition, in each patch, the $V_{\mathrm{t}}$ of shoots belonging to the dominant trees (trees with the tallest shoot) was measured after felling the shoots.

Average age and mean annual tree growth were measured either by extracting discs from the base of fallen shoots or by extracting core samples from the tallest standing tree in each plot. Using ImageJ 1.5 (Schneider et al. 2012) on magnified scaled images, the annual ring widths were measured for the last 43 years (1975-2017) with an accuracy to $0.1 \mathrm{~mm}$. The method of standardization with constant cambial age (Fritts 1976) was used to overcome the cambial aging problem. As a result of the standardization, only 12 of 74 patches with an average age of $57 \pm 5$ years were used for annual mean diameter growth comparisons, creating four replicates in each land-use system. The annual records of total precipitation since 1994, the main climatic factor affecting the width growth of Brant oaks in the region (Esmaeili 2013), were obtained from the Ardal Synoptic Meteorological Station $\left(32.01^{\circ} \mathrm{N}, 50.66^{\circ} \mathrm{E} ; 1875 \mathrm{~m}\right.$ a.s.l.) (Chaharmahal Va Bakhtiari Meteorological Administration 2018).

\section{Data analysis}

The plot data were averaged at the patch level, which made each patch a replication. Using the first and third quartiles and the median values, the continuous data were classified into three distinct classes when necessary (Table 1). The Dixon test was used for dominant height values to remove any outlier plot(s) (Laar and Akça 2007). The data in every set of land-use, verified to be normally distributed

Table 1 Mean with standard deviation and interquartile range (in parenthesis) of dominant height $\left(h_{d}\right)$, quadratic mean diameter at stool level $\left(e_{\mathrm{q}}\right)$, average age and wood volume per hectare $\left(V_{\mathrm{t}}\right)$ in a patch by different land-use treatments

\begin{tabular}{lllll}
\hline Land-use & $h_{d}(\mathrm{~m})$ & $D_{\mathrm{q}}(\mathrm{cm})$ & Age $($ year $)$ & $V_{\mathrm{t}}\left(\mathrm{m}^{3} \mathrm{ha}^{-1}\right)$ \\
\hline Co & $5.7 \pm 0.9$ & $17.2 \pm 4$ & $38.1 \pm 10.2$ & $94.3 \pm 48.7$ \\
& $(1.4)$ & $(7.8)$ & $(18.7)$ & $(75.8)$ \\
CoG & $6.2 \pm 1.0$ & $21.3 \pm 3.8$ & $47.4 \pm 10.0$ & $91.6 \pm 47.6$ \\
& $(2)$ & $(4.6)$ & $(14.1)$ & $(88.7)$ \\
CoCG & $8.1 \pm 0.5$ & $35.5 \pm 6.1$ & $94.4 \pm 20.9$ & $217.1 \pm 59.2$ \\
& $(0.6)$ & $(6.2)$ & $(32.3)$ & $(104.4)$ \\
\hline
\end{tabular}

Co, simple coppice; CoG, coppiced woodlands, with grazing, and CoCG, coppiced woodlands with grazing and cultivation (for part of the year) 
(Kolmogorov-Smirnov test) and have equal variance in each age class (Bartlett's test).

Patches lying outside the predicted interval of the most widely applied growth model, Chapman-Richards function (Richards 1959), were excluded to ensure that the rest of patches are on sites of the same quality. The Chapman-Richards function and its expanded forms are among the most commonly used equations in the development of site index curves (Johnson et al. 2009; Laar and Akça 2007).

An analysis of covariance (ANCOVA), followed by a Tukey post hoc test at $95 \%$ confidence level, was performed to assess the effect of different land-use systems on wood volume per hectare. The average age of the patch was considered as a continuous covariate.

Two-tailed, paired $t$-tests were conducted to assess differences between pairs of mean annual ring growth of trees from different land-use systems. Pearson's correlation analysis $(95 \% \mathrm{CI})$ was used to compare the mean annual ring growth of trees and the total annual precipitation of the last available 24 years with 3-year intervals.

The minimum rotation age of woodlands in each land-use system was estimated using a logarithmic extrapolation of wood volume values versus the average age of the patches.

Considering the $-3 / 2$ power rule (Yoda et al. 1963), a graphic comparison was made between the three landuse systems based on the tendency of their correspondent patches to follow a natural self-thinning trajectory. The rule states that there is a maximum tree size for a given stand density and that, on a $\log -\log$ scale volume $\left(V_{\mathrm{t}}\right)$ equation of $V_{\mathrm{t}}=a N^{b}$ (the mortality line), the power coefficient $(b)$ of the shoot density $(N)$ tends toward -1.5 . Since only a few young and mid-aged patches in Co land-use system could be considered as fully stocked stands, the mortality line that would be the upper limit of stand density obviously could not be calculated for most plots. As noted by Weller (1987), since the homogeneity of the patches was confirmed in all land-use systems, the slope of a least squares power regression that passes through the median was considered in this study as the slope of the self-thinning line.

To verify how stands are likely to change over time in the presence or absence of disturbances, and based on the concept of stand density index (SDI) (Reineke 1933), a log-log plot of $D_{\mathrm{q}}$ against shoot density was designated for each land-use system. To determine whether all patches are evenly distributed over a linear SDI section, segregated SDI values were calculated for each class of quadratic mean diameter for every land-use system, after Reineke (1933): $\log \mathrm{SDI}=\log N+b\left(1-\log D_{\mathrm{q}}\right)$, where $b$ is the calculated power coefficient in the equation of shoot density against volume.

Graphic work, data handling, and analysis were carried out using Excel (Microsoft, Redmond, WA, USA) and Minitab software (Minitab, State College, PA, USA).

\section{Results}

The selection to obtain 74 even-aged coppiced woodlands was particularly accurate, since every data set in each land-use set was normally distributed and had equal variances. The uniform distribution of quadratic mean diameter classes along the proposed growth function model visually showed a strong correlation between tree sizes at different ages (Fig. 2). Using all the average age vs dominant height $\left(h_{d}\right)$ data, the fitted Chapman-Richards' function $\left[h_{d}=8.91\right.$ $\left(1-0.02 \times \exp (-2.77 \times \text { age })^{0.96}\right]$ with coefficient of determination $\left(r^{2}\right)$ of 0.87 , explained all, except three patches. These outlier patches were located outside the prediction interval of the fitted model and removed from further analysis (Fig. 2).

The analysis of covariance showed significant differences in mean wood volume per hectare among the three landuses (Table 2a). Comparisons of the mean wood volumes showed that the differences detected favor the Co land-use system. The production advantage of the Co woodlands over the woodlands in the CoG and CoGC land-use systems was around 43 and $60 \mathrm{~m}^{3} \mathrm{ha}^{-1}$, respectively (Table $2 \mathrm{~b}$ ).

Visually, the mean annual diameter analysis during the past 43 years revealed a similar pattern of wood growth for the three land-uses. The paired $t$ test showed that samples from the Co land-use system generally had higher mean annual diameter growth for most of the period, followed by $\mathrm{CoG}$ land use samples. However, the superiority of the $\mathrm{Co}$ and $\mathrm{CoG}$ samples was not statistically significant over the last 12 years, which coincided with a relative drop in annual precipitation (Fig. 3).

Pearson's correlation analysis results between the total annual precipitation and annual ring growth of the samples from different land-use systems revealed that the woodlands

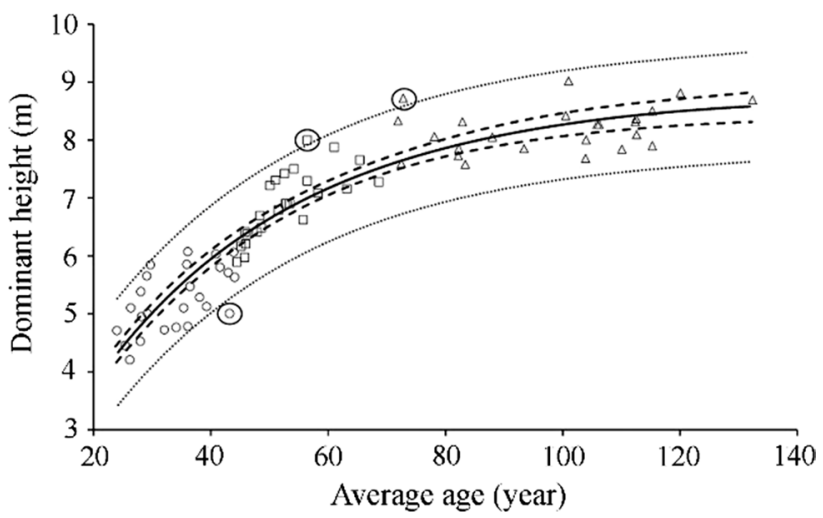

Fig. 2 Fitted Chapman-Richards model of average age versus dominant height of the patches, grouped by quadratic mean diameter classes (small: circles, medium: squares, large: triangles). Three patches (circled) located outside the prediction interval (dotted lines) were considered as outliers and removed from the subsequent analysis 
Table 2 (A) Summary of analysis of covariance statistics for wood volume $\left(\mathrm{m}^{3}\right)$ per hectare under different land-uses, when the patch's age used as a covariate factor. (B) Related comparison of mean wood volume $\left(\mathrm{m}^{3}\right)$ per hectare by three land-uses, using Tukey's method and $95 \%$ confidence

\begin{tabular}{|c|c|c|c|c|}
\hline Source & $\mathrm{df}$ & Mean square & $F$ & $P$ \\
\hline \multicolumn{5}{|l|}{ (A) } \\
\hline Land-use & 2 & 5637 & 6.84 & 0.002 \\
\hline \multicolumn{5}{|l|}{ (B) } \\
\hline Land-use & & No. of patches & & Mean \\
\hline $\mathrm{CoCG}$ & & 25 & & $117.46(b)$ \\
\hline $\mathrm{CoG}$ & & 21 & & $130.97(b)$ \\
\hline Co & & 25 & & 160.94 (a) \\
\hline
\end{tabular}

Means that do not share a small letter in parenthesis are significantly different

df, degrees of freedom; Co, simple coppice; CoG, coppiced woodlands, with grazing, and CoCG, coppiced woodlands with grazing and cultivation (for part of the year)

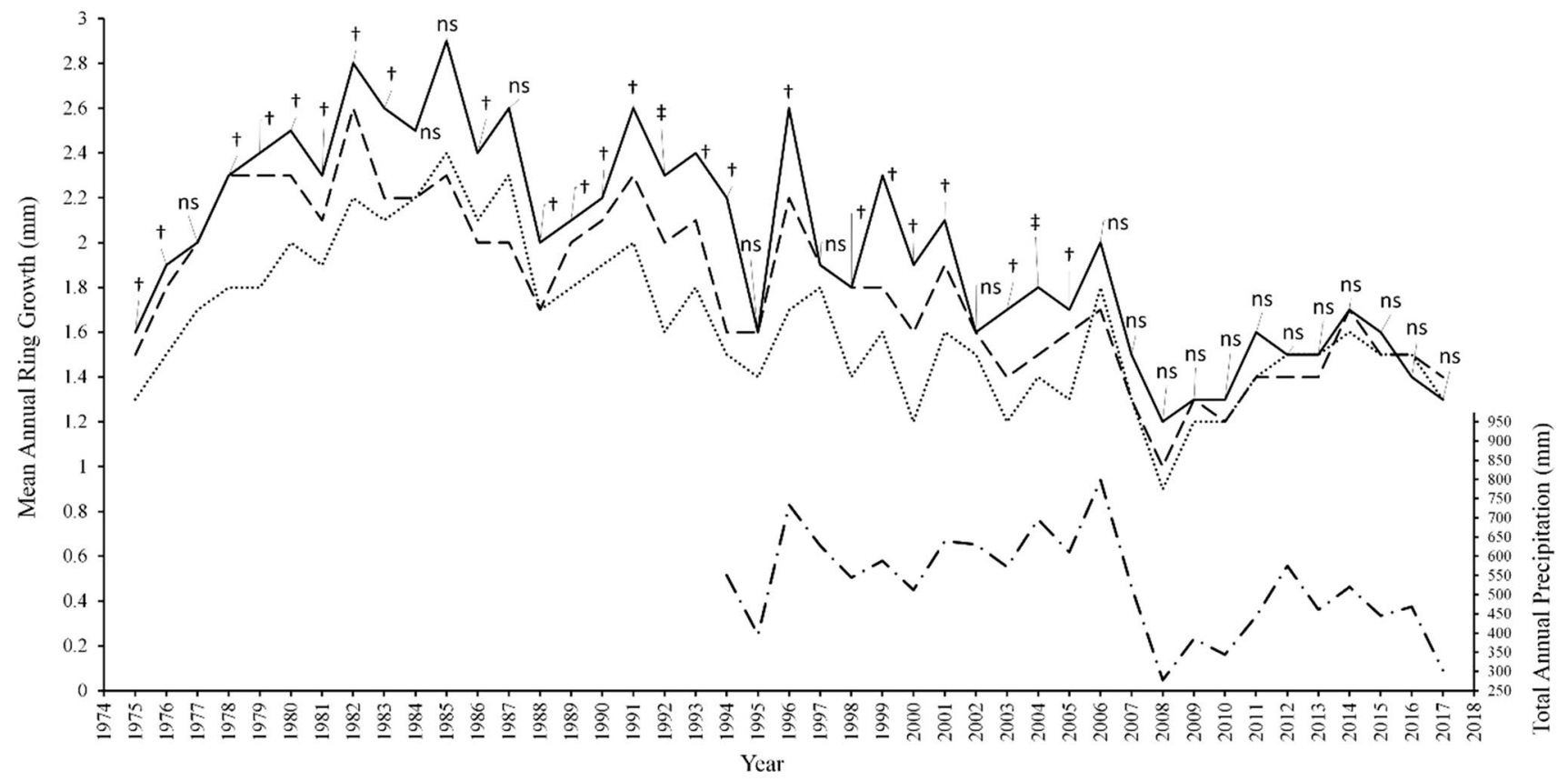

Fig. 3 Time course of change in mean annual ring growth of samples from the three land-uses (Co, simple coppice;: solid line, $\mathrm{CoG}$, coppiced woodlands, with grazing: dashed lin; CoCG, coppiced woodlands with grazing and cultivation: dotted line) over 43 years and total annual precipitation during 1994-2017 at the Ardal Synoptic Mete-

in CoGC system were more affected by the total annual precipitation, as more significant correlation values were obtained from the woodlands treated by this land-use. Woodlands in $\mathrm{Co}$ and $\mathrm{CoG}$ systems showed significant correlations between mean annual diameter growth and the total annual precipitation only during two time periods: $1994-1996$ and 2006-2008 (Table 3).

Calculated logarithmic models fitted on the wood volume values scattered over the average patch's age indicated high orological Station (dotted dashed line). The results of the paired $t$-test analyses between mean growths for the three land-uses are indicated at the year-points on the Co solid line. $\dagger$ One pair of values differs significantly, $¥$ two pairs of values differ significantly different; $n s$ no pair of values differs significantly (95\% confidence)

coefficients of determination (CoGC: 0.81, CoG: 0.89, Co: 0.93). Extrapolation of the regression curves to the lowest accessible wood volume indicates the minimum rotation ages of 30.9 years for the CoGC, 28.9 years for the COG and 23.6 years for the Co land-use (Fig. 4).

The power regression lines $\left(V_{\mathrm{t}}=a N^{b}\right)$ moderately fit the wood volume data as a function of shoot density (coefficients of determination of 0.41 for CoGC, 0.51 for $\mathrm{CoG}$ and 0.55 for Co land-use). According to the stand's rule 
Table 3 Pearson's correlation coefficients of total annual precipitation from the Ardal Synoptic Meteorlogical station and mean annual diameter growth of samples from three land-uses in three-year intervals

\begin{tabular}{lllllllll}
\hline Land-use & $1994-1996$ & $1997-1999$ & $2000-2002$ & $2003-2005$ & $2006-2008$ & $2009-2011$ & $2012-2014$ & $2015-2017$ \\
\hline CoCG & 0.421 & - & 0.468 & 0.470 & 0.683 & - & - & 0.379 \\
CoG & 0.658 & - & - & - & 0.825 & - & - \\
Co & 0.629 & - & - & - & 0.673 & - & - & - \\
\hline
\end{tabular}

Co, simple coppice; CoG, coppiced woodlands, with grazing, and CoCG, coppiced woodlands with grazing and cultivation (for part of the year)

Non-significant correlation values (with less than $95 \%$ confidence) are not shown

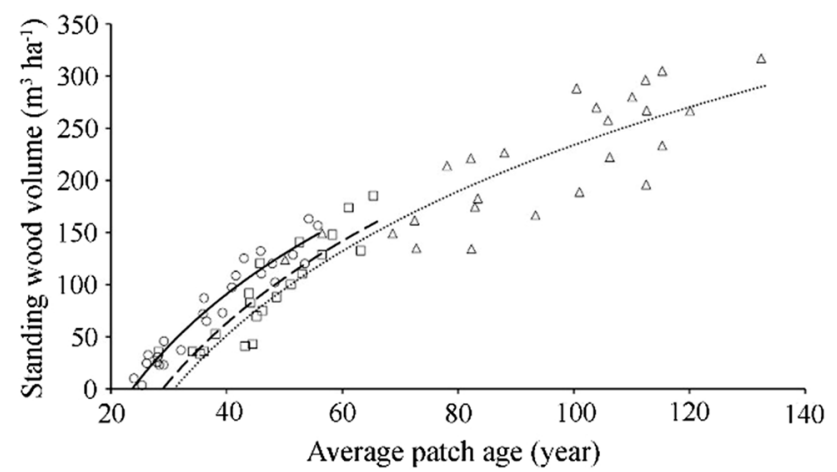

Fig. 4 Extrapolation back to zero of the logarithmic regressions fitted on the wood volume values over the average patch age (considered here as the minimum rotation age), separated by different landuses (Co, simple coppice: solid line, CoG, coppiced woodlands, with grazing: dashed line; CoCG, coppiced woodlands with grazing and cultivation: dotted line)

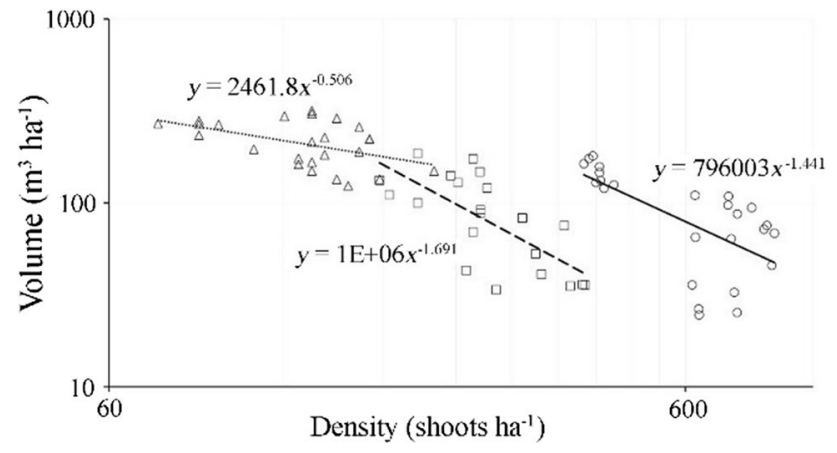

Fig. 5 Power regressions passing through the wood volume values against patch shoot density, assumed to be parallel with the self-thinning lines, separated by different land-uses (Co, simple coppice: solid line, CoG, coppiced woodlands, with grazing: dashed line; CoCG, coppiced woodlands with grazing and cultivation: dotted line)

of $-3 / 2$, the woodlands in the Co and CoG systems with the power coefficient of -1.44 and -1.69 , respectively, are predicted to more likely to shadow the growth of a fully stocked even-aged natural stand, compared to the corresponding coefficient for woodlands in CoGC system $(-0.50)$ (Fig. 5).

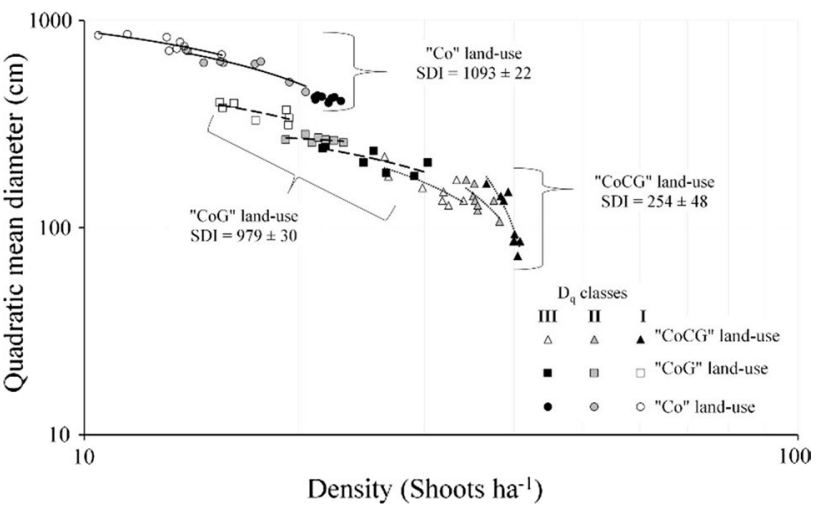

Fig. 6 Double logarithmic graph of the quadratic mean diameter $\left(D_{\mathrm{q}}\right)$ versus patch shoot density, intra-categorized into three discrete $D_{\mathrm{q}}$ subclasses. The mean and standard deviation of the stand density index (SDI) for each land-use system is next to the associated set of data. (Co, simple coppice: solid line, $\mathrm{CoG}$, coppiced woodlands, with grazing: dashed line; CoCG, coppiced woodlands with grazing and cultivation: dotted line)

In terms of density vs quadratic mean diameter, as speculated, different average SDI values were obtained for the three land-uses. The highest SDI value (with more than 1000 unit) belonged to woodlands in Co system (Fig. 6). In the same way, the segregated values for each class of quadratic mean diameter (the sub-SDI), showed little deviation in the sub-SDI values of the $\mathrm{Co}$ and $\mathrm{CoG}$ woodlands (coefficients of variation of 2.01 and $3.06 \%$, respectively), as compared to that of CoGC (coefficient of variation of $18.89 \%$ ). The data from different $D_{\mathrm{q}}$ classes for each land-use system, also showed that unlike the sub-SDI lines in the two land-uses of $\mathrm{Co}$ and $\mathrm{CoG}$, which are in line and parallel to each other, the sub-SDI lines in CoGC land-use system are very misaligned (Fig. 6).

\section{Discussion}

The high coefficient of determination of the growth curve of all patches (Fig. 2) showed that, regardless of the choice of land-use system, $96 \%$ of the randomly selected patches were located on a single growth function (site index of $6.6 \mathrm{~m}$ 
at the age of 50 years). Regardless of the possible equality of the site productivity in the study area, this result might be explained by the fact that the local literatures have regularly considered the Brant's oak as one of the most adaptable tree species in the Zagros (Mohajer 2013). More than that, the homogeneous equality of dominant heights in all the patches can be interpreted as a consequence of a common cause affecting these woodlands, the coppicing itself. Along with the soil fertility decline and nutrient depletion, which is attributed to coppicing (Goldsmith 1992). Unmanaged clear-cuts such as those in the Zagros negatively impact the growth of Brant's oak trees and their rejuvenation ability (Jazireie and Ebrahimi Rostaghi 2013).

The volume of the main product (i.e., wood) has significantly been reduced as a result of adding the other landuse components (grazing and/or cultivation) to the system (Table 2). This result is in agreement with other studies that have demonstrated the deteriorating effect of grazing (Plieninger et al. 2011; Valipour et al. 2014) and understory cultivation (Acácio and Holmgren 2014) on various aspects of oak forests ecosystems, although a decrease in the form of wood production has not been reported.

Detailed local data, such as those used in the study by Ohtsuka et al. (2010) were not available in the current study, for either gross primary production of understory vegetation or grazing livestock density and quantity of dung deposited by them. Nevertheless, what is perceived to be the destructive effects of the historic grazing and cultivation practices on the oak coppices is related to their well-known damaging effects on soil structure and hydrological functioning (Adams 1975).

The results did not show any significant difference in the accumulated wood per hectare after adding the cultivation component to the coppice plus grazing $(\mathrm{CoG})$ system, which can be interpreted as a fundamental negative effect by intensive grazing. Carbon cycle disruption by eliminating considerable amounts of biomass, soil nutrients depletion, and damage to undergrowth root systems have been recognized as the direct consequences of intensive grazing (Klumpp et al. 2009; Mapfumo et al. 2002; Raiesi and Riahi 2014). There were no forest patches with understory cultivation only in the region; if that type of patch existed, it could answer the question of which component has the greatest effect on wood production.

The results also clearly showed that in non-drought years, there is an annual adverse effect of grazing and cultivation on the growth of coppiced semiarid coppiced Brant's oak. Similar to the results of accumulated wood volume, and in agreement with the results of previous work on cork oak high-forest (Acácio 2009; Vargas et al. 2013), annual diameter growth values also indicated the superiority of the protected coppices over three decades (non-drought years). At the same time, no major difference was observed between the two unprotected coppiced woodlands in a sense of annual diameter growth. It can be deduced that in a year with typical rainfall, the diameter growth difference in the semi-arid coppiced oak woodlands can be used as an indicator for a long-term wood production reaction to the main allogenic stresses, in this case, grazing and understory cultivation.

The result of the significant difference between the overall 43-year average wood volume per hectare of Co and the two other land-uses cannot be applied to the last decade (2007-2017) of the study, which has coincided with continuous drought years. During this period, the annual ring growth values of all stand patches in the region were virtually equal, statistically and visually (Fig. 3). Whether this observation is linked to the concept of "diameter increment decrease", as Assmann (1970) coined it, or whether one of the severest documented droughts in the recorded climate history (Arsalani et al. 2018) caused it, the conclusion is following: (1) The annual growth data show that Brant's oak trees grown under different land-use systems, react in a same manner to substantial drop in total annual precipitation. (2) For the reconstruction of past climatic fluctuations in semi-arid regions using dendrochronology analysis, the sampling priority should be oak trees grown in more favored environments (in this study, Co woodlands), since these trees are more affected by the environment regardless of their age. And (3) Brant's oak trees under coppicing regime are able to maintain a minimum diameter growth in a wide range of annual precipitation that may be related in part to its growth nature performance (Oliver and Larson 1996).

As explained in the methodology section, although the concept of minimum rotation age is different from the last use of the phrase by Dwivedi et al. (2012), it acceptably reflects the rotation age (Lee and Kim 1990). The results indicated a one-third increase in minimum rotation age because of the multiple land-use of the Brant's oak coppices. As a main advantage, the short rotation age is the crucial factor for making the right decisions about choosing a coppice system over the common high-forest systems in the first step (Johnson et al. 2009), and recommending a correct thinning and pruning schedule, a timely conversion program, and an optimum density of standards in the second step (Buckley 1992).

The main competition in a coppiced woodland occurs among raments of each genet; therefore, finding the maximum biomass production for each stem density class is problematic (Westoby 1984). Likewise, the logarithmic regressions fitted to the volume-density ceiling spotted values, probably do not represent the real self-thinning lines of different land-use systems as in Portuguese cork oak woodlands (Fonseca et al. 2017). Yet, as shown by Condés et al. (2017) and Yang et al. (2018), it assumes that the fitted regression lines in the present study are either parallel to corresponding lines formed by quantile regressions, or parallel to lines 
passing through ceiling points resulted from a large number of intermediate plots or allometric models (Pretzsch 2009). Thus, we conclude that, although the coppicing is the major stress on these woodlands, the Brant's oak woodlands, even in the presence of extensive grazing, can cope the cutting stress significantly better than when they are under pressure of understory rain-fed cultivation.

Woodlands under both Co and CoG land-use treatments have demonstrated self-thinning coefficients close to $-3 / 2$, which can be speculated as follows: first, the self-thinning rule can be applied to coppiced semi-arid oak woodlands, even though they are constantly exposed to grazing by sheep and goats; and second, the symmetric competition outcome of the stand's rule of $-3 / 2$ (Weiner et al. 2001) allows foresters to schedule stand growing stock based on yield tables for semi-arid oak coppices.

For CoGC patches, the coefficient of self-thinning line was closer to $-1 / 2$, which can be interpreted as a greater independence of the slope of the self-thinning line from site index (Ge et al. 2017) when dealing with a serious disturbance such as understory tillage. Under these conditions, a forester has little choice to improve the growth rate of the stand and its yield simply by establishing a cutting program. Instead, the forester may request a restriction be placed on rain-fed cultivation with the simultaneous short-term exclusion of livestock in CoGC woodlands. On the basis of this result (Fig. 5), and to improve the highly disturbed CoGC woodlands, the study recommends: (1) reforestation with a topping of mid-sized rootstocks to increase shoot density and (2) release of thick shoots from intra-rootstock competition to increase wood volume per hectare.

The SDI diagrams fitted to the patches of the Co woodlands and their corresponding values demonstrate a significant increase in the wood yield (represented by $D_{\mathrm{q}}$ ) due to the decrease in shoot density. The results are in accordance with the allometric principles of Reineke's rule (Pretzsch and Biber 2005). The patches in the CoG and CoGC landuses seem to have little difference in their SDI graphs, while in fact there are more than 500 SDI unit differences between them. It assumes that the difference is due to the greater difference between the sub-SDI units that belong to different $D_{\mathrm{q}}$ classes in the CoGC patches.

Since only shoots with a diameter of more than $10 \mathrm{~cm}$ were considered as a separate individual stem, the SDI values in the current study were much higher than similar values in the North American oak high-forests in the reference work of Williams (2003). No previous work has been found that reports the SDI value for a coppiced oak woodland. Accordingly, maximum SDI values of more than 1000 can be achieved for a semi-arid oak woodland with no other man-made disturbance except coppicing. SDI values of less than 400 (e.g., in CoGC woodlands) are highly likely to reflect irreversible degradation in coppiced oak woodlands due to severe artificial disturbances. In this situation, ordinary improvement cutting techniques can only be effective if long-term protection against understory cultivation becomes mandatory by the government.

\section{Conclusions}

By applying the traditional multi-use systems, the yield and annual growth of semi-arid coppiced oak trees decreased significantly. This result can be seen as an endorsement of the negative view of excessive use of forest resources. Despite initial findings indicating that the volume of accumulated wood and the annual growth of the cultivated and uncultivated woodlands do not differ under intensive grazing, subsequent results showed that the forest structures in the cultivated woodlands have been completely disrupted. The slope of the self-thinning line of cultivated woodlands is far from $-3 / 2$, and their SDI values have fallen too low. The stress induced by the understory rain fed cultivation irreversibly degraded the oak coppices beyond restoration by regular forestry practices. Therefore, for sustainable forest management, traditional understory cultivation, as the most destructive factor, must cease and protection zones must be established in those areas. The results proved that the oak woodlands subjected to coppicing, even when densely grazed by sheep and goats, have a strong tendency toward the $-3 / 2$ rule of self-thinning, suggesting that the simple and the grazed oak coppices can be easily converted to other silvicultural systems.

Acknowledgements We express our appreciation to the 2018 forestry graduate students' team for their great help in data collection. We also gratefully acknowledge the Provincial Natural Resources Bureau for providing us with their archive of journey reports and grazing license contracts. Finally, we appreciate the anonymous reviewers who carefully read the manuscript and made many insightful comments.

Open Access This article is distributed under the terms of the Creative Commons Attribution 4.0 International License (http://creativeco mmons.org/licenses/by/4.0/), which permits unrestricted use, distribution, and reproduction in any medium, provided you give appropriate credit to the original author(s) and the source, provide a link to the Creative Commons license, and indicate if changes were made.

\section{References}

Acácio V (2009) The dynamics of cork oak systems in Portugal: the role of ecological and land use factors. Ph.D. dissertation, Wageningen University, Wageningen, Netherlands

Acácio V, Holmgren M (2014) Pathways for resilience in Mediterranean cork oak land use systems. Ann For Sci 71(1):5-13 
Adams SN (1975) Sheep and cattle grazing in forests: a review. J Appl Ecol 12(1):143-152

Arsalani M, Pourtahamsi K, Azizi G, Bräuning A, Mohammadi H (2018) Tree-ring based December-February precipitation reconstruction in the southern Zagros Mountains, Iran. Dendrochronologia 49(1):45-56

Askari Y (2017) Estimation of Carbon sequestration based on Persian oak (Quercus brantii) and wild almond (Amygdalus arabica) biomass in Zagros forests. Ph.D. Thesis, Shahrekord University

Assmann E (1970) The principles of forest yield study; studies in the organic production, structure, increment, and yield of forest stands, 1st edn. Pergamon Press, New York, p 506

Av Laar, Akça A (2007) Forest mensuration. Springer, Dordrecht, p 390

Bishop RR, Church MJ, Lawson IT, Roucoux KH, O'Brien C, Ranner H, Heald AJ, Flitcroft CE (2018) Deforestation and human agency in the North Atlantic region: archaeological and palaeoenvironmental evidence from the Western Isles of Scotland. Proc Prehist Soc 84:145-184

Buckley GP (1992) Ecology and management of coppice woodlands. Chapman \& Hall, New York, p 336

Burkhart HE, Tomé M (2012) Modeling forest trees and stands. Springer, Dordrecht, p 457

Castro M (2009) Silvopastoral systems in Portugal: current status and future prospects. In: Rigueiro-Rodróguez A, McAdam J, Mosquera-Losada MR (eds) Agroforestry in Europe: current status and future prospects. Advances in Agroforestry. Springer, Dordrecht, pp 111-126

Chaharmahal Va Bakhtiari Meteorological Administration (2018) Ardal Synoptic Meteorological Station. Partly. https://www. chaharmahalmetir

Condés S, Vallet P, Bielak K, Bravo-Oviedo A, Coll L, Ducey MJ, Pach M, Pretzsch H, Sterba H, Vayred J, del Rio M (2017) Climate influences on the maximum size-density relationship in Scots pine (Pinus sylvestris L.) and European beech (Fagus sylvatica L.) stands. For Ecol Manage 385:295-307

Dupouey JL, Dambrine E, Laffite JD, Moares C (2002) Irreversible impact of past land use on forest soils and biodiversity. Ecology 83(11):2978-2984

Dwivedi P, Bailis R, Carter DR, Sharma A (2012) A landscapebased approach for assessing spatiotemporal impacts of forest biomass-based electricity generation on the age structure of surrounding forest plantations in the Southern United States. GCB Bioenergy 4(3):342-357

Esmaeili R (2013) Feasibility of development of Brant's oak forest in Chaharmahal va Bakhtiari province with regard to climatic and topographic conditions (case study: Ardal and Naghan), Shahrekord University

Fonseca T, Monteiro L, Enes T, Cerveira A (2017) Self-thinning dynamics in cork oak woodlands: providing a baseline for managing density. Forest Syst 26(1):8

Fritts H (1976) Tree rings and climate. Elsevier, London, p 583

Fujimori T (2001) Ecological and silvicultural strategies for sustainable forest management. Elsevier, Amsterdam, p 413

Goldsmith FB (1992) Coppicing - a conservation panacea? In: Buckley GP (ed) Ecology and management of coppice woodlands. Springer, Dordrecht, pp 306-312

Gordon AM, Newman SM, Coleman B (2018) Temperate agroforestry systems. CABI, p 327

Iranmanesh Y (2013) Assessment on biomass estimation methods and carbon sequestration of Quercus brantii Lindl. in Chaharmahal va Bakhtiari forests. Ph.D. Thesis, Faculty of Natural Resource and Mariane Science, Tarbiat Modares

Jazireie MH, Ebrahimi Rostaghi M (2013) Silviculture in Zagros. University of Tehran Press, Tehran, p 600
Johnson PS, Shifley SR, Rogers R (2009) The ecology and silviculture of oaks. CABI, Oxfordshire, p 596

Kabukcu C (2018) Identification of woodland management practices and tree growth conditions in archaeological fuel waste remains: a case study from the site of Çatalhöyük in central Anatolia, Turkey. Quat Int 463:282-297

Khaledian Y, Kiani F, Ebrahimi S (2012) The effect of land use change on soil and water quality in northern Iran. J Mt Sci 9(6):798-816

Kleine M, Colak AH, Kirca S, Sagheb-Talebi K, Orozumbekov A, Lee DK (2009) Rehabilitating degraded forest landscapes in West and Central Asia. IUFRO World Ser 20(4):5-26

Klumpp K, Fontaine S, Attard E, Roux XL, Gleixner G, Soussana JF (2009) Grazing triggers soil carbon loss by altering plant roots and their control on soil microbial community. J Ecol 97(5):876-885

Kosmas C, Danalatos NG, Bermúdez FL, Díaz MAR (2002) The effect of land use on soil erosion and land degradation under mediterranean conditions. In: Geeson NA, Brandt CJ, Thornes JB (eds) Mediterranean desertification: a mosaic of processes and respondes. John Wiley \& Sons Ltd., Chichester, pp 57-70

Kumar BM, Nair PKR (2011) Carbon sequestration potential of agroforestry systems: opportunities and challenges. Springer, Berlin, p 317

Le Houerou HN (2000) Restoration and rehabilitation of arid and semiarid mediterranean ecosystems in north Africa and west Asia: a review. Arid Soil Res Rehabil 14(1):3-14

Lee HK, Kim YW (1990) Studies on the rotation age for major tree species. (I). Larix leptolepis, Pinus rigida, Quercus spp. Res Rep For Res Inst Seoul 41:103-113

Mapfumo E, Naeth MA, Baron VS, Dick AC, Chanasyk DS (2002) Grazing impacts on litter and roots: perennial versus annual grasses. J Range Manag 55(1):16-22

Mohajer MRM (2013) Silviculture. Tehran University, Tehran, p 418

Mohammadpour M, Tatian MR, Tamartash R, Hossienzadeh J (2018) Investigating the effects of grazing intensity on the structure and diversity of woody species in the Ilam Strait Dalab forest. Iranian J Forest Poplar Res 26(3):306-318

Müllerová J, Hédl R, Szabó P (2015) Coppice abandonment and its implications for species diversity in forest vegetation. For Ecol Manag 343:88-100

Nyland RD (2016) Silviculture: concepts and applications, 3rd edn. Waveland Press, Long Grove, p 704

Ohtsuka T, Shizu Y, Nishiwaki A, Yashiro Y, Koizumi H (2010) Carbon cycling and net ecosystem production at an early stage of secondary succession in an abandoned coppice forest. J Plant Res 123(4):393-401

Oliver CD, Larson BC (1996) Forest stand dynamics. Wiley, New York, $\mathrm{p} 550$

Pardo F, Gil L (2005) The impact of traditional land use on woodlands: a case study in the Spanish Central System. J Hist Geogr 31(3):390-408

Plieninger T, Schaich H, Kizos T (2011) Land-use legacies in the forest structure of silvopastoral oak woodlands in the Eastern Mediterranean. Reg Environ Change 11(3):603-615

Pretzsch H (2009) Forest dynamics, growth and yield: from measurement to model. Springer, Berlin, p 664

Pretzsch H, Biber P (2005) A re-evaluation of Reineke's rule and stand density index. Forest Sci 51(4):304-320

Raiesi F, Riahi M (2014) The influence of grazing exclosure on soil C stocks and dynamics, and ecological indicators in upland arid and semi-arid rangelands. Ecol Ind 41:145-154

Reid R (2009) Growing high-quality sawlogs. In: Nuberg I, George BH, Reid R (eds) Agroforestry for natural resource management. CSIRO Publishing, Collingwood, pp 161-182

Reineke LH (1933) Perfecting a stand-density index for even-aged forests. J Agric Res 46(7):627-638 
Richards FJ (1959) A flexible growth function for empirical use. J Exp Bot 10(2):290-301

Sadeghi Kaji H, Soltani A (2017) Single tree volume modeling for even age Persian oak (Quercus brantii) coppice in Central Zagros (Case study: Chaharmahal va Bakhtiari province, Ardal and Kiar district). Iran J Forest 9(3):361-372

Salehi A, Wilhelmsson E, Söderberg U (2008) Land cover changes in a forested watershed, southern Zagros, Iran. Land Degrad Dev 19(5):542-553

Schneider CA, Rasband WS, Eliceiri KW (2012) NIH Image to ImageJ: 25 years of image analysis. Nat Methods 9:671-675

Soares P, Tomé M, Skovsgaard JP, Vanclay JK (1995) Evaluating a growth model for forest management using continuous forest inventory data. For Ecol Manage 71(3):251-265

Soltani A, Sankhayan PL, Hofstad O (2015) A recipe for co-management of forest and livestock-Results of bio-economic model at a village level in Iran. Agric Syst 140:74-86

Valipour A, Plieninger T, Shakeri Z, Ghazanfari H, Namiranian M, Lexer MJ (2014) Traditional silvopastoral management and its effects on forest stand structure in northern Zagros, Iran. Forest Ecol Manag 327:221-230

Vargas JdD, Huntsinger L, Starrs PF (2013) Raising livestock in Oak Woodlands. In: Campos P, Huntsinger L, Oviedo Pro JL, Starrs PF, Diaz M, Standiford RB, Montero G (eds) Mediterranean Oak Woodland Working Landscapes: Dehesas of Spain and Ranchlands of California. Landscape Series. Springer, Dordrecht, pp 273-310

Vincent J, Binkley CS (1993) Efficient multiple-use forestry may require land-use specialization. Land Econ 69(4):370-376
Weiner J, Stoll P, Muller-Landau H, Jasentuliyana A (2001) The effects of density, spatial pattern, and competitive symmetry on size variation in simulated plant populations. Am Nat 158(4):438-450

Weller DE (1987) A reevaluation of the $-3 / 2$ power rule of plant selfthinning. Ecol Monogr 57(1):23-43

Westoby M (1984) The self-thinning rule. In: Macfadyen A, Ford ED (eds) Advances in ecological research, vol 14. Academic Press, London, pp 167-225

Williams RA (2003) Use of stand density index as an alternative to stocking percent in upland hardwoods. Northern J Appl For 20(3):137-142

Xu Z, Bradley DP, Jakes PJ (1995) Measuring forest ecosystem sustainability: a resource accounting approach. Environ Manag 19(5):685-692

Yang TR, Lam TY, Kershaw JA (2018) Developing relative stand density index for structurally complex mixed species cypress and pine forests. For Ecol Manag 409:425-433

Yoda K, Kira T, Ogawa H, Hozumi K (1963) Self-thinning in overcrowded pure stands under cultivated and natural conditions (intraspecific competition among higher plants. XI). J Biol Osaka City Univ 14:107-129

Publisher's Note Springer Nature remains neutral with regard to jurisdictional claims in published maps and institutional affiliations. 